Pacific Journal of Mathematics

ADDENDUM TO: "LIPCHITZ CONVERGENCE O 


\title{
ADDENDUM TO
}

\section{LIPSCHITZ CONVERGENCE OF RIEMANNIAN MANIFOLDS}

\author{
R. E. GREene AND H. WU \\ Volume 131 (1988), 119-142
}

It has come to the authors' attention that certain papers relevant to their paper were not cited in the original bibliography. Specifically, I. G. Nikolaev pointed out to us the relevance of his paper [3], which treats spaces of bounded curvature in the sense of A. D. Aleksandrov. He also pointed out the paper [4], which deals with the use of harmonic functions as coordinates on surfaces. The reader can consult [1] for a survey of the work of the Russian school on these and related subjects. (It is worth noting that the English language version of [1] appeared after the authors had completed the paper presently being amended.) Some further remarks on Soviet contributions to the use of harmonic functions as coordinates can be found in [2]. The authors regret their inadvertent omission of these references from the Russian literature.

\section{REFERENCES}

[1] A. D. Aleksandrov, V. N. Berestovskiǐ, I. G. Nikolaev, Generalized Riemannian Spaces, Uspekhi Mat. Nauk, 41 (1986), No. 3, 1-54.

[2] J. Kazdan, Prescribing the Curvature of a Riemannian Manifold, Conf. Board Math. Sciences, Number 57, American Mathematical Society, Providence, Rhode Island, 1985.

[3] I. G. Nikolaev, Parallel translation and smoothness of the metric of spaces of bounded curvature, Dokl. Akad. Nauk SSSR, 250 (1980), 1056-1058 = Soviet Math. Dokl., 21 (1980), 263-265.

[4] I. Kh. Sabitov and S. Z. Shefel', Connections between the order of smoothness of a surface and that of its metric, Sibirsk. Mat. Zh., 17 (1976), 916-925 = Siberian Math. J., 17 (1976), 687-694. 


\section{PACIFIC JOURNAL OF MATHEMATICS EDITORS}

\author{
V. S. VARAdarajan \\ (Managing Editor) \\ University of California \\ Los Angeles, CA 90024-1555-05 \\ Herbert Clemens \\ University of Utah \\ Salt Lake City, UT 84112 \\ ThOMAS ENRIGHT \\ University of California, San Diego \\ La Jolla, CA 92093
}

R. FINN

Stanford University

Stanford, CA 94305

HeRmann FlaschKa

University of Arizona

Tucson, AZ 85721

VAUGHAN F. R. Jones

University of California

Berkeley, CA 94720

SteVen KercKhofF

Stanford University

Stanford, CA 94305

\section{ROBION KIRBY}

University of California

Berkeley, CA 94720

C. C. MOORE

University of California

Berkeley, CA 94720

HAROLD STARK

University of California, San Diego

La Jolla, CA 92093

\section{ASSOCIATE EDITORS}
R. Arens
E. F. BeCKenbaCH
B. H. NEUMANN
F. Wolf
K. YoshidA (1906-1982)

\section{SUPPORTING INSTITUTIONS}

UNIVERSITY OF ARIZONA

UNIVERSITY OF BRITISH COLUMBIA

CALIFORNIA INSTITUTE OF TECHNOLOGY

UNIVERSITY OF CALIFORNIA

MONTANA STATE UNIVERSITY

UNIVERSITY OF NEVADA, RENO

NEW MEXICO STATE UNIVERSITY OREGON STATE UNIVERSITY

\author{
UNIVERSITY OF OREGON \\ UNIVERSITY OF SOUTHERN CALIFORNIA \\ STANFORD UNIVERSITY \\ UNIVERSITY OF HAWAII \\ UNIVERSITY OF TOKYO \\ UNIVERSITY OF UTAH \\ WASHINGTON STATE UNIVERSITY \\ UNIVERSITY OF WASHINGTON
}

The Supporting Institutions listed above contribute to the cost of publication of this Journal, but they are not owners or publishers and have no responsibility for its content or policies.

Mathematical papers intended for publication in the Pacific Journal of Mathematics should be in typed form or offset-reproduced (not dittoed), double spaced with large margins. Please do not use built up fractions in the text of the manuscript. However, you may use them in the displayed equations. Underline Greek letters in red, German in green, and script in blue. The first paragraph must be capable of being used separately as a synopsis of the entire paper. In particular it should contain no bibliographic references. Please propose a heading for the odd numbered pages of less than 35 characters. Manuscripts, in triplicate, may be sent to any one of the editors. Please classify according to the scheme of Math. Reviews, Index to Vol. 39. Supply name and address of author to whom proofs should be sent. All other communications should be addressed to the managing editor, or Elaine Barth, University of California, Los Angeles, California 90024-1555-05.

There are page-charges associated with articles appearing in the Pacific Journal of Mathematics. These charges are expected to be paid by the author's University, Government Agency or Company. If the author or authors do not have access to such Institutional support these charges are waived. Single authors will receive 50 free reprints; joint authors will receive a total of 100 free reprints. Additional copies may be obtained at cost in multiples of 50 .

The Pacific Journal of Mathematics is issued monthly as of January 1966. Regular subscription rate: $\$ 190.00$ a year (5 Vols., 10 issues). Special rate: $\$ 95.00$ a year to individual members of supporting institutions.

Subscriptions, orders for numbers issued in the last three calendar years, and changes of address should be sent to Pacific Journal of Mathematics, P.O. Box 969, Carmel Valley, CA 93924, U.S.A. Old back numbers obtainable from Kraus Periodicals Co., Route 100, Millwood, NY 10546.

The Pacific Journal of Mathematics at P.O. Box 969, Carmel Valley, CA 93924 (ISSN 0030-8730) publishes 5 volumes per year. Application to mail at Second-class postage rates is pending at Carmel Valley, California, and additional mailing offices. Postmaster: send address changes to Pacific Journal of Mathematics, P.O. Box 969, Carmel Valley, CA 93924.

PUBLISHED BY PACIFIC JOURNAL OF MATHEMATICS, A NON-PROFIT CORPORATION Copyright (C) 1989 by Pacific Journal of Mathematics 


\section{Pacific Journal of Mathematics \\ Vol. 140, No. $2 \quad$ October, 1989}

Edoardo Ballico, Spanned and ample vector bundles with low Chern numbers

Marcy Mason Barge, Richard Swanson and Russell Bruce Walker,

Conjugacy class structure of smooth hyperbolic sectors . ........... 217

Jeffrey Stephen Fox, Adeles and the spectrum of compact nilmanifolds . . ..233

Robert D. Little, Homotopy complex projective spaces with divisible

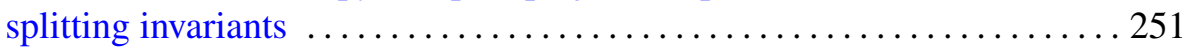

M. Scott Osborne and Garth William Warner, Jr., The Selberg trace formula. VII. Application of the truncation process to the continuous

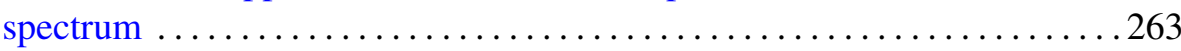

John R. Stembridge, On the eigenvalues of representations of reflection

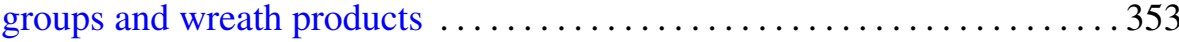

Ibrahim Salama, Corrections to: "Topological entropy and recurrence of

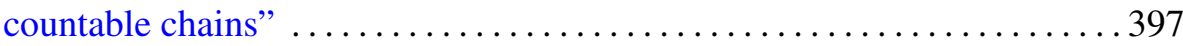

Robert Greene and Hung-Hsi Wu, Addendum to: "Lipschitz convergence of Riemannian manifolds" ............................... 398

Kayoko Shikishima-Tsuji, Correction to: "Galois theory of differential fields of positive characteristic" 